\author{
MAREK SANAK \\ Zakład Biologii Molekularnej i Genetyki Klinicznej \\ II Katedra Chorób Wewnętrznych im. Prof. A. Szczeklika \\ Uniwersytet Jagiellonski Collegium Medicum \\ Skawińska 8, 31-066 Kraków \\ E-mail: marek.sanak@uj.edu.pl
}

\title{
GENETYKA PANDEMII COVID-19
}

\section{HISTORIA PANDEMII COVID-19}

Stan pandemii COVID-19, choroby spowodowanej zakażeniem koronawirusem SARS-CoV-2, trwa już prawie dwa lata. Powoduje to poważne skutki społeczne i gospodarcze w skali całego świata, porównywalne do globalnych konfliktów zbrojnych.

Historycznego podobieństwa obecnej sytuacji epidemicznej można się doszukać w pandemii wywołanej wirusem grypy A1H1 (hiszpanki) w latach 1918-1920. Chorowało wtedy około 500 milionów ludzi, czyli 1/3 ówczesnej populacji. Grypa hiszpanka spowodowała śmierć od 17 do 50 milionów ludzi. W latach 1890-1892 inny koronawirus spowodował również pandemię nazywana wtedy rosyjska grypa (VIJGEN i współaut. 2005). Przechorowało około 300-800 milionów ludzi, zmarło przypuszczalnie milion chorych. Ten historyczny koronawirus sprzed 130 lat nadal jest obecny w populacji człowieka. Nazywa się OC43 i z czasem się zmienił, obecnie powodując łagodne zakażenia układu oddechowego, nieodróżnialne od innych przeziębień.

Pierwsze zakażenia wirusem SARS-CoV-2 u ludzi, czyli poczatek obecnej pandemii, stwierdzono w chińskim Wuhan pod koniec listopada 2019 r. W tej dużej aglomeracji miejskiej, stolicy prowincji Hubei, znajduje się ośrodek badań wirusologicznych - Wuhan Institute of Virology. Zbieżność miejsca wybuchu pandemii $z$ obecnościa wirusologicznego ośrodka badawczego spowodowa- ła spekulacje dotyczace pochodzenia wirusa SARS-CoV-2. Analiza jego sekwencji nukleotydowej, a dokładniej częstości wykorzystania kodonów poszczególnych aminokwasów, przeczy spiskowej teorii wyprodukowania SARS-CoV-2 w warunkach laboratoryjnych (HUSSAIN i współaut. 2021). Sa jednak inne niepotwierdzone doniesienia o pobieraniu przez pracowników Instytutu $z$ Wuhan próbek $\mathrm{z}$ populacji dzikich nietoperzy do badań naukowych. Przypadkowe zakażenie pracownika byłoby bardziej prawdopodobna okolicznościa pojawienia się "pacjenta zero”, niż podejrzenia dotyczace handlu żywymi zwierzętami na targu $\mathrm{w}$ Wuhan. Do rozprzestrzenienia wirusa SARS-CoV-2 przyczyniły się podróże lotnicze. Ogniska zakażenia wybuchały również na statkach morskich, luksusowych wycieczkowcach czy okrętach wojskowych, ale tam można było sytuacje łatwo zlokalizować. Główna przeszkoda w ograniczeniu rozprzestrzeniania się pandemii spowodowanej COVID-19 (nazwę choroby zaproponowała Światowa Organizacja Zdrowia; ang. coronavirus disease-2019) był dość częsty (około 20\%) bezobjawowy lub łagodny przebieg zakażenia, który przypominał przeziębienie. Dodatkowo, potwierdzono zakażanie innych osób już w okresie wylęgania choroby, co najmniej dobę przed pojawieniem się objawów. W celu ograniczenia tempa rozprzestrzeniania choroby wprowadzono ograniczenia $\mathrm{w}$ skali niespotykanej $\mathrm{w}$ ostatnich dekadach. Było to podyktowane obawami dotyczacymi ograniczonych zasobów 
szpitalnych, potrzebnych do ratowania osób chorujących ciężko.

Czas, jaki upływa między ekspozycja na wirusa a pojawieniem się objawów zakażenia i zakaźności dla innych, wynosił początkowo średnio 6 dni. Tłumaczy to szybkość rozprzestrzeniania się pandemii. Bez sanitarnych ograniczeń, dorosła populacja Polski uległaby w całości zakażeniu w ciagu 22 tygodni. Podczas pandemii zaobserwowano takie początkowe tempo rozprzestrzeniania się wirusa w kilku krajach, np. w Brazylii i USA. W Europie szybki przyrost liczby chorych pojawił się $\mathrm{w}$ początkowym etapie epidemii we Włoszech i Hiszpanii, w mniejszym stopniu w Wielkiej Brytanii.

O tempie rozprzestrzeniania sie nowego wirusa SARS-CoV-2 w nieodpornej populacji decyduje jego podstawowy wskaźnik reprodukcji $\left(\mathrm{R}_{0}\right)$, czyli uśredniona liczba osób zakażajacych się od jednego chorego. Dla SARS-CoV-2 ten współczynnik został oszacowany na około 2,4-3,1. Tyle osób ulegało zakażeniu po kontakcie $\mathrm{z}$ jednym chorym, uwalniajacym droga kropelkowa zakaźne czasteczki wirusa podczas mówienia, kichania lub kaszlu. Dla porównania, w sezonowej grypie $R_{0}$ wynosi zazwyczaj około 1,4. Współczynnik ten ma oczywiście inna wielkość w obszarach wiejskich o małej liczbie kontaktów międzyludzkich, a inną w dużych zakładach pracy albo podczas imprez zbiorowych. Dobrze udokumentowano zjawiska super-przenoszenia i super-przenosicieli SARS-CoV-2. W rozgrywce piłkarskiej Ligii Mistrzów 19 lutego 2020 r. spotkały sie w Mediolanie zespoły Atalanta Bergamo i hiszpańskiej Valencii CF. To zdarzenie, związane $z$ udziałem blisko 50 tys. kibiców włoskich świętujących po meczu zwycięstwo swojej drużyny, przyniosło około 7 tys. nowych zakażeń. Objęły one również połowę składu piłkarskiego drużyny z Walencji (LOPEZ i współaut. 2021). Przykładem zakażenia licznych osób przez super-przenosiciela była przebywajaca w domu opieki w Kirkland, Stan Waszyngton, 73 letnia kobieta (pacjentka zero). Zakaziło się od niej łącznie 129 osób, w tym 81 innych pensjonariuszy, 34 pracowników i 14 odwiedzajacych ten zakład opieki. Badania naukowe wykazały, że podczas kichania, kaszlu, również śpiewania, a nawet głośnego mówienia, liczba uwalniany cząsteczek areozolu $z$ dróg oddechowych wzrasta ponad kilkudziesięciokrotnie, co sprzyja rozsiewaniu wirusa (ScHIJVEN i współaut. 2021). Brak jest natomiast wiarygodnych dowodów na udział w szerzeniu pandemii wirusa przenoszonego przez przedmioty. W szczególności, komentowane $\mathrm{w}$ codziennych gazetach odkrycia obecności wirusa na opakowaniach produktów żywno-

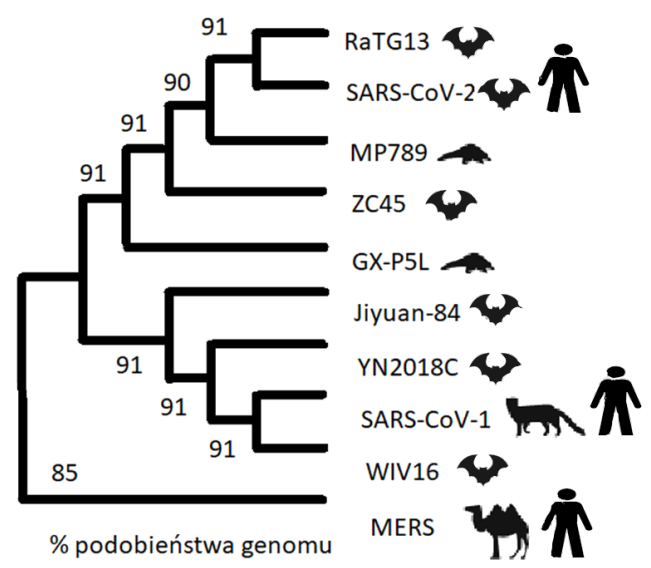

Ryc. 1. Drzewo podobieństwa genetycznego ludzkich i zwierzęcych koronawirusów. Gatunkami pośredniczącymi w przeskoku wirusów SARS-CoV-1 na człowieka były wiwery palmowe, natomiast dla wirusa MERS wielbłądy (wg GANESH i współaut. 2021, zmieniona).

ściowych nie wydają się znacząca droga jego transmisji.

\section{ŹRÓDŁO WIRUSA SARS-CoV-2}

SARS-CoV-2 jest przedstawicielem beta-koronawirusów. Zakaźne dla człowieka wirusy $z$ tego rodzaju pojawiły się wskutek międzygatunkowego przeskoku od nosicieli zwierzęcych. Dwa gatunki, wspomniany OC43 i HKU1, sa przyczyna sezonowych nieżytów oddechowych. Podobnie, dwa alfa-koronawirusy (NL63 i 229E) również krąża w populacji człowieka, powodując objawy przeziębienia. Pierwotnymi nosicielami koronawirusów sa ssaki, rzadziej ptaki. Nietoperze sa szczególnym naturalnym rezerwuarem koronawirusów (Ryc. 1). Kolonie nietoperzy tworza duże skupiska w miejscach odpoczynku i podczas zimowania. W tych koloniach dochodzi do wzajemnego zakażania się zwierzat. Nietoperze sa dobrze przystosowane do nosicielstwa koronawirusów i same nie choruja. Warto podkreślić, że wśród zwierzat zidentyfikowano dotychczas kilkaset koronawirusów. Koci koronawirus (FCoV) jest alfa-koronawirusem spotykanym nawet u $80 \%$ zwierzat. Psy zakażaja się dwoma koronawirusami: psim jelitowym koronawirusem (alfa-koronawirus CECoV, powoduje biegunkę zwłaszcza u szczeniat) i psim oddechowym koronawirusem (beta-koronawirus CRCoV, do 60\% zwierzat). Ptasi gamma-koronawirus zakaźnego zapalenia oskrzeli (IBV) może spowodować nawet 100\% śmiertelność drobiu hodowanego w fermach. Podczas obecnej pandemii opisane zostały zakażenia 
psów i kotów wirusem SARS-CoV-2, jednak przebieg takiego zakażenia jest bezobjawowy (KORATH i współaut. 2021).

\section{CECHY EPIDEMICZNEGO ZAKAŻENIA KORONAWIRUSOWEGO}

Wirus może spowodować zapalenie płuc - akronim SARS oznacza zespół ciężkiej ostrej niewydolności oddechowej. Chory $z$ ciężkim przebiegiem COVID-19 nie może samodzielnie podtrzymać wymiany gazowej w płucach, polegajacej na wchłanianiu tlenu do krwiobiegu i wydychaniu dwutlenku węgla. Szanse na wyzdrowienie daje wspomaganie czynności oddechowych przez podawanie tlenu lub, w najcięższych przypadkach, wentylacja mechaniczna $z$ użyciem respiratora. U dużego odsetka (40-70\%) tych chorych dochodzi do nieodwracalnego uszkodzenia płuc, niewydolności krążenia, nerek i śmierci. Przebiegowi COVID-19 towarzyszy zwiększone ryzyko wykrzepiania krwi w naczyniach krwionośnych, powodujące występowania zatorowości i udarów (Ho i współaut. 2021).

W ostatnich latach już dwukrotnie zdarzyły się epidemie spowodowane innymi koronawirusami, o zdecydowanie mniejszej zakaźności (Ryc. 1). Po raz pierwszy zdarzyło się to w Chinach (SARS-CoV-1, 2002). Wirus dokonał przeskoku na człowieka od wiwer palmowych, przy czym był to tzw. gatunek pośredniczacy, bowiem pierwotnym źródłem były nietoperze. Po raz drugi inny koronawirus zaatakował w Arabii Saudyjskiej (MERS, 2012), gatunkiem pośredniczącym były wielbłady. Oba te wirusy charakteryzowała duża śmiertelność $z$ powodu zapalenia płuc u osób zakażonych. Niewydolność oddechowa spowodowana zapaleniem płuc miała charakterystyczny obraz radiologiczny płuc, śmiertelność wynosiła od 10 do $40 \%$ chorych. Jednak łaczna liczba chorych na SARS i MERS nie przekroczyła 10 tysięcy. Było to spowodowane niewielkim podstawowym współczynnikiem reprodukcji tych wirusów $R_{0}(0,1-0,4)$. $Z$ tej perspektywy można tłumaczyć zaskoczenie Światowej Organizacji Zdrowia oraz krajowych organizacji zdrowia szybkością rozprzestrzeniania i rozmiarem obecnej pandemii COVID-19. Pandemia ujawniła również brak przygotowania przemysłu farmaceutycznego do produkcji leków przyczynowo zwalczających chorobę. Podczas szczytu pandemii zabrakło łóżek i respiratorów w oddziałach intensywnej terapii w chińskich, włoskich, brazylijskich i indyjskich szpitalach. Leki, których rozwój rozpoczęto w zwiąku z SARS-CoV-1 po 2002 r., nie zostały przebadane klinicznie ani zarejestrowane. Było to nieopłacalne ze względu na mała populację chorych na SARS albo MERS (FORD i współaut. 2020).

\section{OBECNY STAN EPIDEMICZNY W POLSCE}

Łączna liczba osób zakażonych SARS-CoV-2 w Polsce od 4.03.2020 wynosi 2 miliony 922 tysięcy (stan na 10 października 2021). Badanie laboratoryjne wykrywa zakażenie na podstawie polimerazowej reakcji łańcuchowej powielajacej fragment materiału genetycznego wirusa. Jest wykonywane po wyizolowaniu RNA $z$ wydzieliny górnych dróg oddechowych. Opracowane zostały również szybkie testy antygenowe, wykrywające $w$ tym samym materiale obecność białek kodowanych przez RNA wirusa. Badanie słabo rozróżnia osoby zakażone i aktywnie uwalniajace cząsteczki zakaźne wirusa, od osoby, która jeszcze jest nosicielem materiału genetycznego wirusa lub białkowego, lecz zakażenie już zwalczyła. Przebycie zakażenia powoduje pojawienie się we krwi przeciwciał dajacych co najmniej czasowa odporność na nowe zakażenie. Przesiewowe badania populacji polskiej na obecność przeciwciał we krwi sugeruja, że zakażenie SARS-CoV-2 przebyło około $20 \%$ populacji, natomiast niewiele ponad $50 \%$ osób powyżej 12 roku życia ma przeciwciała nabyte po szczepieniu. Ten łaczny (70\%) odsetek uodpornienia populacji polskiej charakteryzuje znaczna zmienność geograficzna. Aktualnie najwięcej nowych zakażeń jest obserwowanych w regionach Polski, których mieszkańcy niechętnie się szczepili. W miejscach, w których zachorowała więcej niż co dziesiąta osoba w populacji (np. Floryda, USA), proporcja osób niezdiagnozowanych w czasie zakażenia sięga $20 \%$ i koreluje zarówno $z$ częstością przebiegu bezobjawowego, jak i $z$ oszacowaniem nabytej odporności pozakaźnej w Polsce. Problem $z$ identyfikacją chorych na COVID-19 wynika $z$ pospolitości objawów, które sa wspólne dla wielu zakażeń wirusowych, podobnych do sezonowej grypy. Poza uczuciem zmęczenia i pobolewaniem mięśni, są to goraczka i suchy kaszel. Jako jeden $z$ bardziej swoistych objawów wymieniało się utratę powonienia i uczucie braku smaku potraw, co mogło trwać około 2 tygodnie. Ze względu na zmiany genetyczne wirusa, aktualnie występujace jego warianty rzadziej daja utratę powonienia, częściej natomiast dołączaja się objawy obejmujące układ pokarmowy: biegunka, ból brzucha i wymioty. Wskazaniem do hospitalizacji chorego na COVID-19 jest pojawienie się duszności; chory zgłasza brak tchu i niezdolność do podejmowania wysiłku fizycznego. Osoby bez duszności i cech zapalenia płuc w ba- 
daniach RTG moga się leczyć w domu, o ile nie maja współistniejących chorób sercowo-naczyniowych lub onkologicznych. Z przyczyn sanitarno-epidemiologicznych, jeśli nie jest możliwa izolacja domowa, osoby lekko chore umieszczane były w izolatoriach. Kwarantanna domowa obowiazuje wszystkich, którzy pozostawali w kontakcie $z$ chorym, przy czym zrezygnowano $z$ wymogu uzyskania ujemnego wyniku badania wymazu $z$ gardła po 2 tygodniach od ostatniego kontaktu. Arbitralnie wyznacza się czas kwarantanny na 10 dni. Strategia zwalczania choroby, polegajaca na izolacji osoby zakaźnej jest skuteczna, jeżeli uwzględnia wszystkie osoby $z$ kontaktu $z$ chorym. Jest jednak zupełnie nieskuteczna, jeśli osoba zakażona nie czuje się chora i nie ma objawów choroby. Stą zalecenia dotyczace przesłaniania nosa i ust, mycia rak i utrzymywania dystansu w kontaktach społecznych. Jak wszystkie choroby zakaźne dróg oddechowych, COVID-19 przenosi się droga kropelkowa. Najbardziej zakaźne sa kaszlace osoby $z$ aktywnymi objawami zakażenia. Obecność wirusa można wykryć na powierzchni przedmiotów, ubrań i ciała, wystawionych na osiadanie aerozolu produkowanego podczas kaszlu. Jest możliwe, że zakaźność cząsteczek wirusa na przedmiotach i ubraniach przetrwa kilkadziesiąt godzin. Ze względu na lipidowa otoczkę wirusa, zwykłe detergenty i mydło, nie wspominajac o alkoholowych roztworach odkażajacych, sa dla wirusa zabójcze.

\section{MECHANIZM ZAKAŻENIA I ODPOWIEDZI ODPORNOŚCIOWEJ}

Wirus SARS-CoV-2 wnika do komórek nabłonka dróg oddechowych wykorzystujac obecność na ich błonie komórkowej białka ACE2 (patrz WITKOWSKI i BRYL w tym zszycie KOSMOSU). Jest to błonowy enzym, który trawi peptydy angiotensyny II do angiotensyny 1-7, czasteczki działającej przeciwstawnie do angiotensyny II zbudowanej z 9 aminokwasów. Białko kolca wirusa (ang. spike, S) pasuje do N-terminalnej domeny peptydazowej ACE2. Po zwiazaniu $z$ komórka, kształt wirusowego kolca zmienia się, wyzwalając proces połączenia się otoczki wirusa $z$ błoną komórkowa. Uczestnicza $\mathrm{w}$ tym własne enzymy proteolityczne komórki nabłonka oddechowego. Powstaje pęcherzyk cytoplazmatyczny, w którym rozłożona na składniki cząsteczka wirusa uwalnia swoje RNA do cytoplazmy. Cząsteczka RNA wirusa jest zbudowana $z \quad 30$ tysięcy rybonukleotydów. Ma sygnał lokalizacji rybosomalnej i dzięki niemu bezpośrednio koduje białka (nić dodatnia albo sensowna). Największym genem wirusa jest tzw. otwarta ramka odczytu 1 ab. Gen orf1ab koduje większość białek potrzebnych do replikacji wirusa. W wyniku jego translacji rybosomy uwalniaja długi polipeptyd, który zostaje pocięty przez zakodowany na samym jego początku enzym - proteinazę wirusowa podobna do papainy. Jest to enzym proteolityczny rozpoznający sekwencję cięcia aminokwas hydrofobowy-arginina lub lizyna. W ten sposób powstaje 14 białek niestrukturalnych wirusa, wśród których enzym polimeraza RNA zależna od RNA i helikaza sa niezbędne dla kopiowania i namnożenia RNA wirusa (genomu). Liczba kopii genomu SARS-CoV-2 może wynosić wiele tysięcy na komórkę. Wśród innych białek niestrukturalnych sa egzorybonukleaza i endorybonukleaza, odpowiedzialne za oporność wirusa na wiele leków, będacych analogami nukleotydowymi stosowanymi w zakażeniach wirusami RNA. Pozostałe odcinki genomu SARS-CoV-2 koduja białka strukturalne, takie jak wspomniane już białko kolca, nukleoproteinę tworzaca kompleks $z$ genomowym RNA w zakaźnych cząsteczkach wirusa (N), białko błonowe (M) i małe białko otoczki (E). Składanie cząsteczek zakaźnych wirusa ma miejsce $\mathrm{w}$ pęcherzykach cytoplazmatycznych, $z$ których wirus może być uwalniany przez egzocytozę bez uszkodzenia komórki, albo masywnie zakażona komórka nabłonka oddechowego się rozpada, uwalniając tysiące zakaźnych cząsteczek. Wirus może zakazić również inne komórki mające na powierzchni ACE2, w tym makrofagi i komórki śródbłonka naczyń. Jednak replikacja wirusa w innych komórkach nie zachodzi lub jest słaba. Większość objawów ogólnoustrojowych jest spowodowana uwalnianiem przez zakażone komórki substancji białkowych nazywanych cytokinami prozapalnymi. Sa wśród nich interleukiny, np. odpowiedzialna za wzrost ciepłoty ciała interleukina- 6 oraz interleukina-8 powodujaca napływ granulocytów z naczyń włosowatych do zrębu płuca. Komórki wrodzonego układu odporności człowieka, do których należą monocyty i osiadłe $\mathrm{w}$ tkankach makrofagi, uwalniaja cytokiny prozapalne, ponieważ obecność wirusowego RNA jest rozpoznawana przez obecne $\mathrm{w}$ ich cytoplazmie receptory. Sa to receptory wzorca patogenu, nazywane $\mathrm{w}$ języku angielskim toll-like receptors, np. TLR-3 i TLR-8. Po kilku dniach od zakażenia białka wirusowe, prezentowane przez komórki dendrytyczne jako obce antygeny, pobudzaja limfocyty T. Limfocyty pomocnicze $T$ powoduja namnożenie limfocytów B zdolnych do produkcji swoistych przeciwciał, poczatkowo klasy IgM, a po upływie około 2 tygodni pojawiaja się w krążeniu przeciwciała klasy IgG. Te właśnie przeciwciała silnie wiążą się $z$ biał- 
kami wirusa, blokując w ten sposób jego możliwość wnikania do komórek. Nazywane sa przeciwciałami neutralizującymi. W samoistnym wyleczeniu się $z$ COVID-19 uczestniczą również wyspecjalizowane limfocyty $\mathrm{T}$ cytotoksyczne, które rozpoznają zakażone komórki i je zabijają. Szczepienia ochronne naśladuja zakażenie poprzez dostarczenie do komórki instrukcji dotyczącej syntezy białka kolca (patrz JANKOWIAK i TRZONKOWSKI w tym zeszycie KOSMOSU). W szczepionkach RNA jest to zoptymalizowany w kierunku efektywnej translacji na rybosomach gen strukturalny S, w szczepionce wektorowej ten sam gen jest ulokowany $w$ adenowirusie niezdolnym do namnażania w komórkach człowieka. Po szczepieniu pojawiaja się również limfocyty cytotoksyczne, jednak pomiary ich aktywności sa bardziej skomplikowane niż oznaczenia poziomu przeciwciał przeciwko białku $\mathrm{S}$ wirusa we krwi.

\section{ZMIENNOŚĆ GENETYCZNA CZŁOWIEKA A PRZEBIEG COVID-19}

Porównania sekwencji genomu osób, które przebyły ciężkie zakażenie COVID-19 z osobami chorujacymi łagodnie ujawniły predyspozycje genetyczne do nasilenia klinicznego zakażenia. Maja na nie wpływ nawet dziedziczone przez człowieka grupy krwi, jednak ich efekt jest bardzo niewielki. Geny człowieka o najsilniejszym wpływie ochronnym przed ciężkim zachorowaniem na COVID-19 znajduja się na chromosomie 12. Jest to klaster genów OAS, kodujacych syntazę oligoadenylową. Cząsteczki składające się $z 2$ do 5 nukleotydów adenylowych połączonych wiazaniem fosfodiestrowym 2'-5' indukują w komórce aktywność rybonukleazy L, enzymu degradujacego wirusowe RNA i hamujaccego jego replikację. Warianty genetyczne odcinka DNA kontrolujacego ekspresję genów OAS moga powodować niedobór syntaz oligoadenylowych, zwiększając kilkukrotnie ryzyko niewydolności oddechowej u zakażonej osoby (PAIRO-CASTINEIRA i współaut. 2021).

Ciężki przebieg zakażenia koreluje $z$ nasileniem zapalenia płuc i niewydolności nerek, przy czym stwierdza się nadmierna produkcję przez komórki odporności wrodzonej wspomnianych cytokin prozapalnych. Śmiertelność osób $z$ udokumentowanym zakażeniem COVID-19 jest oceniania globalnie na $0,4 \%$, może jednak przekraczać $5 \%$ (w Polsce aktualnie 2,6\%), jeśli liczyć jedynie zakażonych objawowo COVID-19 (https:// ourworldindata.org). Istnieje silny zwiazek między wiekiem osoby zakażonej a śmiertelnością. Dotyczy to zwłaszcza seniorów (po 60 roku życia), u których aktywność układu odporności jest mniejsza, natomiast $\mathrm{w}$ tej grupie wiekowej wzrasta częstość chorób

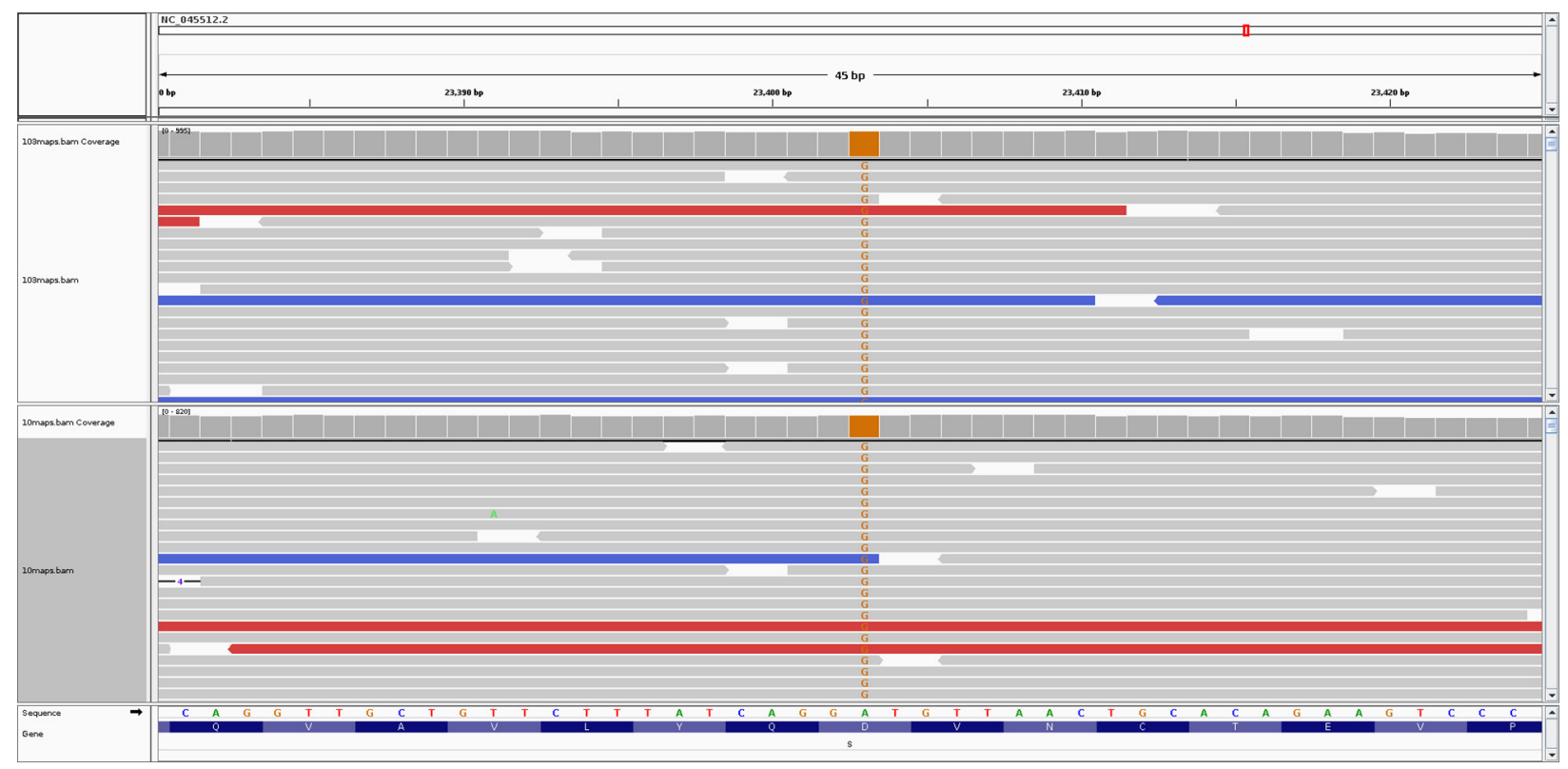

Ryc. 2. Sekwencjonowanie genomu wirusa technika nowej generacji polega na odczycie kilku milionów fragmentów kodu genetycznego o wielkości 150 nukleotydów każdy, które się następnie układa według sekwencji wzorcowej Wuhan przy użyciu oprogramowania komputerowego. Oryginalny szczep SARS-CoV-2 powodujacy pierwsze zachorowania w Europie (G) został wyizolowany od jednego pierwszych chorych w Polsce (marzec 2020 r.) i ma typową mutację D614G w genie kodującym białko S. Materiał własny. 
przewlekłych. Szczególnie silnym czynnikiem ryzyka dla ciężkiego przebiegu COVID-19 jest cukrzyca i otyłość.

\section{ZMIENNOŚĆ GENETYCZNA SARS-CoV-2 W CZASIE PANDEMII}

Poznano wiele szczegółów dotyczacych właściwości genetycznych wirusa SARS-CoV-2. Zmienia on swoja sekwencję RNA podczas replikacji dość często $z$ powodu niedokładności polimerazy RNA, jednak obserwowane tempo mutacji $\mathrm{w}$ próbkach izolowanych od chorych jest wolne. Jest tak, ponieważ większość przypadkowych mutacji nie sprzyja utrzymaniu aktywności zakaźnej wirusa albo jest wobec niej neutralna. Opisywane warianty zakaźne, różniące się wobec pierwotnego szczepu Wuhan, pojawiaja się podczas transmisji wirusa do nowych regionów świata. Naturalny mechanizm mutacji zostaje wtedy wzmocniony procesem selekcji pozytywnej, prowadzac do dominacji w poszczególnych krajach i podczas różnych fal zakażeń nowymi wariantami. Poczatkowo w Europie dominował nieznacznie bardziej zakaźny wariant $z$ mutacja kwasu asparaginowego na glicynie $\mathrm{w}$ pozycji aminokwasowej 614 białka S (D614G) (Ryc. 2).
Wiẹkszość nowych wariantów SARS-CoV-2 pojawia się wskutek mutacji jego białka S. Losowe zamiany aminokwasowe w sekwencji tego białka zwiększaja zakaźność wirusa przez lepsze dopasowanie kolca wirusa do cząsteczki ACE2. Po pierwszej fali zakażeń w Europie (wiosna 2020) spowodowanej wariantem D614G pojawily się nowe mutacje. Po raz pierwszy zidentyfikowany na $\mathrm{Wy}-$ spach Brytyjskich, a obecnie nazywany alfa wariant wywołał jesienia 2020 r. dużą liczbę zakażeń (Tabela 1). W Polsce zarejestrowano szczyt zakażeń spowodowanych wariantem alfa pod koniec marca 2021 r. Równolegle z wariantem alfa, w 2020 r. pojawił się zakaźny wariant beta, bardziej odporny na przeciwciała neutralizujace. Został zidentyfikowany po raz pierwszy w Republice Południowej Afryki, natomiast nie rozprzestrzenił sie w Europie. Wariant gamma wywołał fale zakażeń w Ameryce Południowej. Obecne zachorowania sa spowodowane wariantem delta, który po raz pierwszy zidentyfikowano w Indiach. W obu Amerykach stwierdza się obecnie występowania wariantu mu, rzadko spotykanego w Europie. Wprowadzenie nazw pochodzacych od liter greckiego alfabetu miało uwolnić od negatywnych skojarzeń kraje, w których po raz pierwszy zidentyfi-

Tabela 1. Najważniejsze warianty wirusa powodujące najliczniejsze zachorowania na świecie.

\begin{tabular}{|c|c|c|c|c|c|}
\hline $\begin{array}{l}\text { Nazwa } \\
\text { WHO }\end{array}$ & Nazwa Pango & $\begin{array}{l}\text { Gałą́ ewolucyjna } \\
\text { GISAID }\end{array}$ & $\begin{array}{l}\text { Zamiany amino- } \\
\text { kwasów }\end{array}$ & $\begin{array}{l}\text { Najwcześniej wy- } \\
\text { kryta próbka }\end{array}$ & $\begin{array}{l}\text { Kraj odkrycia wariantu } \\
\text { wirusa }\end{array}$ \\
\hline \multirow[t]{4}{*}{ Alfa } & B.1.1.7 & GRY & $\mathrm{L} 18 \mathrm{~F}$ & 18 grudnia 2020 & Wielka Brytania \\
\hline & & & N501Y & & \\
\hline & & & A570D & & \\
\hline & P 1351 & CH /501V V & D614G & & Ponublitro Pohudniowai \\
\hline \multirow{4}{*}{ Beta } & B. 1.051 & GH/5OIY.V2 & K $417 \mathrm{~N}$ & 18 grudnia 2020 & Republika Połudnıwej \\
\hline & & & E484K & & Afryki \\
\hline & & & N501Y & & \\
\hline & & & D614G & & \\
\hline \multirow{2}{*}{ Gamma } & P.1 & GR/501Y.V3 & $\begin{array}{l}\text { A701V } \\
\text { K417T }\end{array}$ & stycznia & Brazylia \\
\hline & & & E484K & 2021 & \\
\hline \multirow{7}{*}{ Delta } & & & N501Y & & \\
\hline & & & D614G & & \\
\hline & & & H655Y & & \\
\hline & B.1.617.2 & G/478K.V1 & L452R & październik 2020 & Indie \\
\hline & & & T478K & & \\
\hline & & & D614G & & \\
\hline & & & P681R & & \\
\hline
\end{tabular}

WHO - Swiatowa Organizacja Zdrowia, Pango - ang. Phylogenetic assessment of named global outbreak, GISAID - Globalna Inicjatywa Wymiany Danych dotyczących Grypy, analizująca również dane wirusa SARS-CoV-2. Użyto jednoliterowych kodów aminokwasów dla sekwencji białka kolca wirusa (S). 


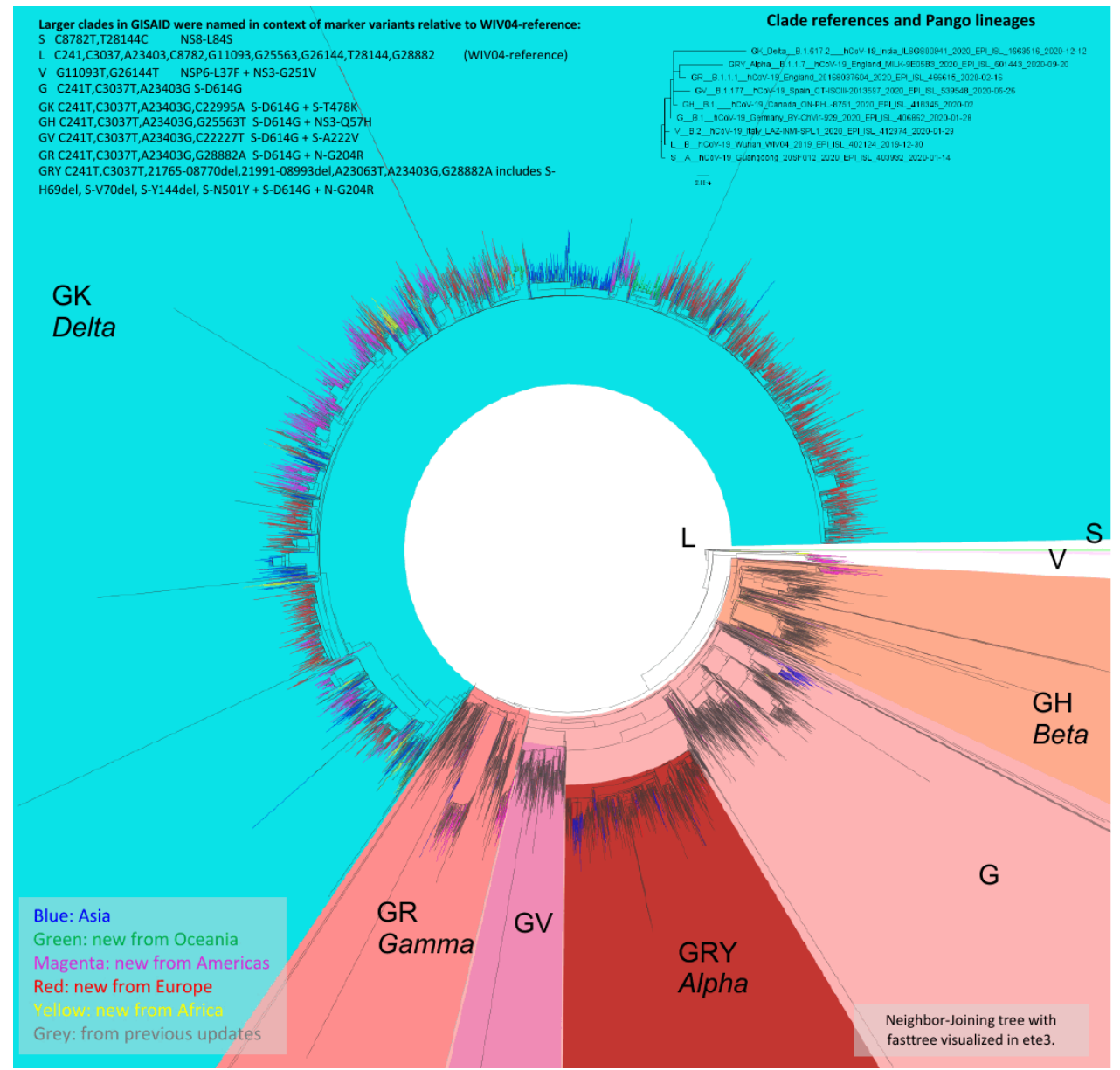

\section{Sampled genome tree derived from all outbreak sequences 2021-10-08}

$$
\begin{aligned}
& \text { Notable changes } \\
& \text { (excludin genomes }(+111,305) \\
& \begin{array}{r}
\text { (excluding low coverage, out of } \\
4,111,635 \text { entries) }
\end{array} \\
& \begin{array}{l}
\text { Updated clades } \\
\text { RBDX: relevant changes near receptor }
\end{array}
\end{aligned}
$$

$$
\begin{aligned}
& \text { We gratefully acknowledge } \\
& \text { the Authors from Originating } \\
& \text { and Submitting laboratories } \\
& \text { of sequence data on which the } \\
& \text { analysis is based. }
\end{aligned}
$$

\section{CISAID}

Ryc. 3. Diagram przedstawia względne liczebności zsekwencjonowanych próbek wirusa SARS-CoV-2 klasyfikowanych na podstawie gałęzi ewolucyjnych. W sposób pośredni odzwierciedlaja one liczbę zakażeń różnymi szczepami wirusa. Rysunek został wygenerowany z bazy sekwencji GISAID (www.gisaid. org) i przedstawia stan na 10 października 2021 uwzględniający sekwencje 4 milionów 227 tys. izolatów wirusa.

kowano nowe warianty wirusa. Preferowana klasyfikacja nowych szczepów zakaźnych wirusa na podstawie wyników sekwencjonowania ich genomu jest bardziej precyzyjna i opiera się na klastrach podobieństwa sekwencji. Przykładowo, wariant brytyjski to alfa, czyli B.1.1.7, natomiast najczęstszy wariant indyjski to delta, czyli B.1.617.2 (Tabela 1, Ryc. 3). Warto zaznaczyć, że izolowane od chorych próbki wirusa często się różnia innymi pojedynczymi nukleotydami sekwencji, poza genem S. Dla uznania ich za warianty obaw (ang. variant of concern), istotne jest wykazanie zwiększonej zakaźności lub oporności na przeciwciała poszczepienne lub produkowane przez ozdrowieńców. Przykładami mutacji, $z$ zapisem jednoliterowych kodów aminokwasów, zwiększających zakaźność są: D614G i N501Y, podczas gdy zamiany aminokwasowe L452R, E484K koreluja $z$ gorszym blokowaniem wirusa przez przeciwciała neutralizujące (SHRESTA i współ- aut. 2021). Ze względu na brak leków zaprojektowanych do hamowania namnażania wirusa SARS-CoV-2, do leczenia COVID-19 zarejestrowano pojedyncze preparaty stosowane w leczeniu chorób wirusowych. Takim lekiem jest analog nukleotydowy o nazwie remdesiwir, skracajacy czas zakażenia COVID-19. Lek ten zostal pierwotnie zarejestrowany do leczenia Eboli i jego skuteczność wobec koronawirusa jest ograniczona (ANSEMS i współaut. 2021).

\section{KIEDY KONIEC PANDEMII?}

Po wybuchu pandemii COVID-19 załamał się transport lotniczy, turystyka oraz masowa kultura i sztuka. Edukacja, praktycznie przez cały rok szkolny, odbywała się zdalnie. Nastepstwa wirtualnego nauczania uczniów i studentów poznamy dopiero za jakiś czas. Już teraz można natomiast oszacować finansowe skutki ograniczenia ruchu 
transgranicznego, wzrostu kosztów transportu publicznego, obsługi urzędów, a przede wszystkim ochrony zdrowia. Opóźnione diagnozy chorób, odłożone wizyty i zabiegi lekarskie będa rzutować przez następne lata na zdrowotność społeczeństwa. Zakładajac rychly koniec pandemii COVID-19, ponieważ historyczne pandemie trwały zazwyczaj 2-3 lata, pojawia się pytanie, czy można było jej zapobiec. W poszukiwaniu przyczyn pandemii w skali globalnej, warto przypomnieć, że Światowa Organizacja Zdrowia ostrzegła o stanie zagrożenia dla zdrowia publicznego o zasięgu międzynarodowym już 30 stycznia 2020 r. COVID-19 nazwano pandemia 11 marca 2020 r. Tradycyjne i znane od setek lat procedury izolacji chorych oraz osób $z$ kontaktu zakaźnego okazały sie mało skuteczne. Poza wspomnianym zmiennym stopniem nasilenia choroby $i$ jej zakaźnościa, prawdopodobnie nie spełniły oczekiwań $z$ powodu ich częstego naruszania. Program szczepień ograniczył liczbę osób wymagających hospitalizacji $z$ powodu ciężkiego przebiegu COVID-19 i był w praktyce dostępny od stycznia 2021 r. Pozostaje zatem mieć nadzieję na szybkie naturalne wygaśnięcie obecnej pandemii. SARS-CoV-2 zapewne dołaczy do kilku innych sezonowo zakażających koronawirusów. Pozostana jednak obawy, czy w przyszłości kolejny wirus, pokonując barierę międzygatunkowa, nie poczyni podobnego spustoszenia wśród ludzi. Przecież podatność człowieka na zakażenia wirusowe, chęć podróżowania, kontestacja narzucanych ograniczeń sanitarnych i bezkrytyczna wiara we własne zdrowie jest zapisana $\mathrm{w}$ naszych genach.

\section{Streszczenie}

Błyskawiczne rozprzestrzenianie się zakażenia wirusem SARS-CoV-2 ma swoja przyczyne nie tylko w biologii tego łatwo przekazującego się zakażenia, lecz również w zwiększeniu mobilności globalnej populacji oraz szybkości transportu międzynarodowego. $Z$ perspektywy historycznej, pandemie wirusowe występowały już w czasach nowożytnych, były spowodowane przeskokiem na człowieka wirusa $z$ rezerwuaru zwierzęcego i również objęły setki milionów mieszkańców ziemi. Dzięki osiagnięciom diagnostyki molekularnej i nowym metodom sekwencjonowania jesteśmy świadkami bieżacej oceny stanu epidemicznego indywidualnych populacji oraz szybkiej ewolucji wirusa. Wpływ tych osiagnięć medycyny na sam przebieg pandemii pozostał umiarkowany. Największe sukcesy w jej opanowaniu odniosły izolowane geograficznie Australia i Nowa Zelandia, które po prostu zamknęły granice zewnętrzne i wprowadziły wielomiesięczne restrykcje dla obywateli. Zostały opracowane szczepionki przeciwko COVID-19, które przetestowano i zatwierdzono do zastosowania. Ich działanie ochronne przed ciężkim zachorowaniem nie budzi watpliwości. Jednak następna fala zakażeń COVID-19 ogarnia kolejne kraje, zmienia się jedynie struktura demograficzna chorych, którym młodszy wiek i dobre samopoczucie dawało ułude wrodzonej odporności.

\section{LITERATURA}

Ansems K., GRUndeis F., Dahms K., MikolajewSKA A., THIEME V., PIECHOTTA V. i współaut., 2021. Remdesivir for the treatment of COVID-19. Cochrane Database Syst. Rev. 8, doi: 10.1002/14651858.CD014962.

FORD N., VITORIA M., RANGARAJ A., NORRIS S.L., CALMY A., DOHERTY M., 2020. Systemic review of the efficacy and safety of antiretroviral drugs against SARS, MERS or COVID-19: initial assessment. J. Int. AIDS Soc. 23, doi: $10.1002 /$ jia2.25489.

GANESH B., RAJAKUMAR T., MALATHU M., MANIKANDAN N, NAGARAJ J., SANTHAKUMAR A. i współaut, 2021. Epidemiology and pathobiology of SARS-CoV-2 (COVID-19) in comparison with SARS, MERS: An updated overview of current knowledge and future perspectives. Clin. Epidemiol. Global Health 10, doi. org/10.1016/j.cegh.2020.100694.

Ho F. K., MaN K. K. C., Church C., CelisMorales C., WONG I. C. K., BerRy C., i współaut., 2021. Thromboembolic risk in hospitalized and nonhospitalized COVID-19 patients: a self-controlled case series analysis of a nationwide cohort. Mayo Clin. Proc. 96, 2587-2597.

Hussain A., Rasool S. T., PotTahil S., 2021. The evolution of severe acute respiratory syndrome coronavirus-2 during pandemic and adaptation to the host. J. Mol. Evol., doi: 10.1007/ s00239-021-10008-2.

Korath A. D. J., JANDA J., UnTERSMAYR E., SoKOLOWSKA M., FELESZKO W., AGACHE I., SEIDA A. A. i współaut., 2021. One health: EAACI position paper on coronaviruses at the humananimal interface, with a specific focus on comparative and zoonotic aspects of SARS-CoV-2. Allergy doi: 10.1111/all.14991.

LOPEZ M. G., Chiner-OMS A., DE Viedma D. G., Ruiz-Rodriguez P., BRANCHO M. A., CANCINOMUNOZ I. i wspólaut., 2021. The first wave of the COVID-19 epidemic in Spain was associated with early introductions and fast spread of a domination genetic variant. Nat. Genet. 53, 1405-1414.

Pairo-Castineira E., Clohisey S., Klaric L., BRETHERIC A. D., RAWLIK K., PASKO D. i współaut., 2021. Genetic mechanisms of critical illness in COVID-19. Nature 591, 92-98.

SCHIJVEN J., Vermeulen L. C., Swart A., MeIJER A., Duizer E., DE Roda HuSman A. M., 2021. Quantitative microbial risk assessment for airborne transmission of SARS-CoV-2 via breathing, speaking, singing, coughing, and sneezing. Environ. Health Perspect. 129, doi: 10.1289/EHP7886.

Shresta L. B., TeDlA N., Bull R. A., 2021. Broadly-neutralizing antibodies against emerging SARS-CoV-2 variants. Front. Immunol. 12, doi: 10.3389 /fimmu.2021.752003.

ViJgen L., KeyaerTS E., MOES E., THOElen I., WOLlants E., LEMEY P., VANDAMME A.-M., VAN RANTS M., 2005. Complete genomic sequence of human coronavirus OC43: molecular clock analysis suggests a relatively recent zoonotic transmission event. J. Virol. 79, 1595-1604. 
KOSMOS Vol. 70, 3, 389-397, 2021

\author{
MAREK SANAK
}

Division of Molecular Biology and Clinical Genetics, Department of Internal Medicine, Jagiellonian University Collegium Medicum, 8 Skawińska Str., 31-066 Kraków,E-mail: marek.sanak@uj.edu.pl

\title{
GENETICS OF COVID-19 PANDEMICS
}

\section{Summary}

The rapid spread of SARS-CoV-2 infection is due not only to the biology of this easily transmissible virus, but also to the increased mobility of the global population and the speed of international transport. From a historical perspective, viral pandemics have already occurred in modern times, were caused by the virus switching to humans from an animal reservoir and also affected hundreds of millions of inhabitants of the earth. Thanks to the advancements of molecular diagnostics and new sequencing methods, we are witnessing an ongoing assessment of the epidemic state of individual populations, and the rapid evolution of the virus. The impact of these medical achievements on the course of the pandemic itself has remained moderate. The most successful in control of pandemics were geographically isolated Australia and New Zealand, which simply closed their external borders and introduced months of restrictions for citizens. Vaccines against COVID-19 have been developed that following rapid clinical tests were approved for use. Their protective effect against severe illness is beyond doubt. However, the next wave of COVID-19 infections is sweeping more countries, only that the demographic structure of patients is changing, whose younger age and well-being gave a delusion of innate immunity.

Keywords: coronavirus SARS-CoV-2, COVID-19 pandemics, genetic susceptibility to infection, genetic variants of the virus 